\title{
XXXIII. ORSZÁGOS TUDOMÁNYOS DIÁKKÖRI KONFERENCIA: A TDK TOVÁBBRA IS A TUDÓSKÉPZÉS LEGFÖBB BÁZISA
}

\section{$33^{\text {RD }}$ NATIONAL CONFERENCE OF STUDENT RESEARCH SOCIETIES: STUDENT RESEARCH ACTIVITIES FORM THE MAIN BASE OF SCIENTIFIC REPLENISHMENT}

\author{
Cziráki Szabina', Szabó István², Szendrő Péter \\ 'doktorandusz, Nemzeti Közszolgálati Egyetem Közigazgatás-tudományi Doktori Iskola, cziraki.szabina@gmail.com \\ ${ }^{2} \mathrm{PhD}$, föosztályvezető, Emberi Erőforrások Minisztériuma Felsőoktatás- és Kutatásstratégiai Főosztály \\ ${ }^{3} \mathrm{DSc}$, rector emeritus, Szent István Egyetem
}

\section{ÖSSZEFOGLALÁS}

\begin{abstract}
A tudományos diákköri tevékenység (TDK) és az Országos Tudományos Diákköri Konferencia (OTDK) elsődleges célja a tudományos utánpótlás biztosítása, ugyanakkor látszik, hogy ezen feladat ellátása közben úgy változik, hogy más területeken is egyre inkább hasznosítható tudást kapnak a részt vevő fiatalok. Jelen cikkben bemutatjuk, hogy a TDK milyen, a munkaerőpiac által igényelt kompetenciák fejlesztéséhez járul hozzá, és az OTDK mint tudományos fórum, verseny és konferencia, valamint annak szervezése, felépítése mindezt hogyan támogatja, segíti.
\end{abstract}

\section{ABSTRACT}

The primary purpose of student research activities and the National Conference of Student Research Societies is providing scientific supply, nevertheless it seems that while doing this, it is changing to provide young people more and more exploitable knowledge in other areas. In this article we will show how the student research activities contribute to the development of the competences demanded by the labour market, and how the National Conference of Student Research Societies as a scientific forum, a place for competition and as a conference organizer and holder supports this.

Kulcsszavak: TDK, OTDK, XXXIII. Országos Tudományos Diákköri Konferencia, Pro Scientia Aranyérem, Mestertanár Aranyérem

Keywords: Scientific Students' Associations, National Scientific Students' Associations Conference, XXXIIIrd Congess of the National Scientific Students' Associations Conference, Pro Scientia Gold Medal, Master Teacher Gold Medals 
„Viszonylag kevés olyan lehetősége van egy felsőoktatásban tanuló diáknak, amellyel a tantervi órákon felül is fejlesztheti azokat a készségeit, amelyek a későbbi munkája során nagy hasznára lehetnek. A TDK-munka tökéletesen alkalmas erre, hiszen a kutatás elkészítése, abból egy tanulmány megírása, majd az eredmények kommunikálása a kari Tudományos Diákköri Konferencián, később pedig egy nagyobb közösség elött az Országos Tudományos Diákköri Konferencián, olyan kihívások elé állítja a hallgatókat, amelyekkel a tantermi keretek között nem találkoznak. Úgy gondolom, az, aki részt vállal ebben a folyamatban, az a munkája során sokkal könnyebben fog boldogulni, ha valamilyen nyilvánosság előtti beszédre vagy valamilyen önálló szellemi termék elöállítására kérik fel. Persze a TDK-munka nem az egyetlen lehetőség, de kihagyni nem érdemes." Nagy Andor, OTDK első helyezett és Pro Scientia Aranyérmes hallgató - aki az 1. képen átveszi a kitüntetését - válasza az „Ajánlaná-e alsóbb éves egyetemista ismerőseinek a TDK-munkát; ha igen, mivel érvelne?" kérdésre a XXXIII. Országos Tudományos Diákköri Konferencia Pedagógiai, Pszichológiai, Andragógiai és Könyvtártudományi Szekciójának kiadványában (Nagy, 2017).

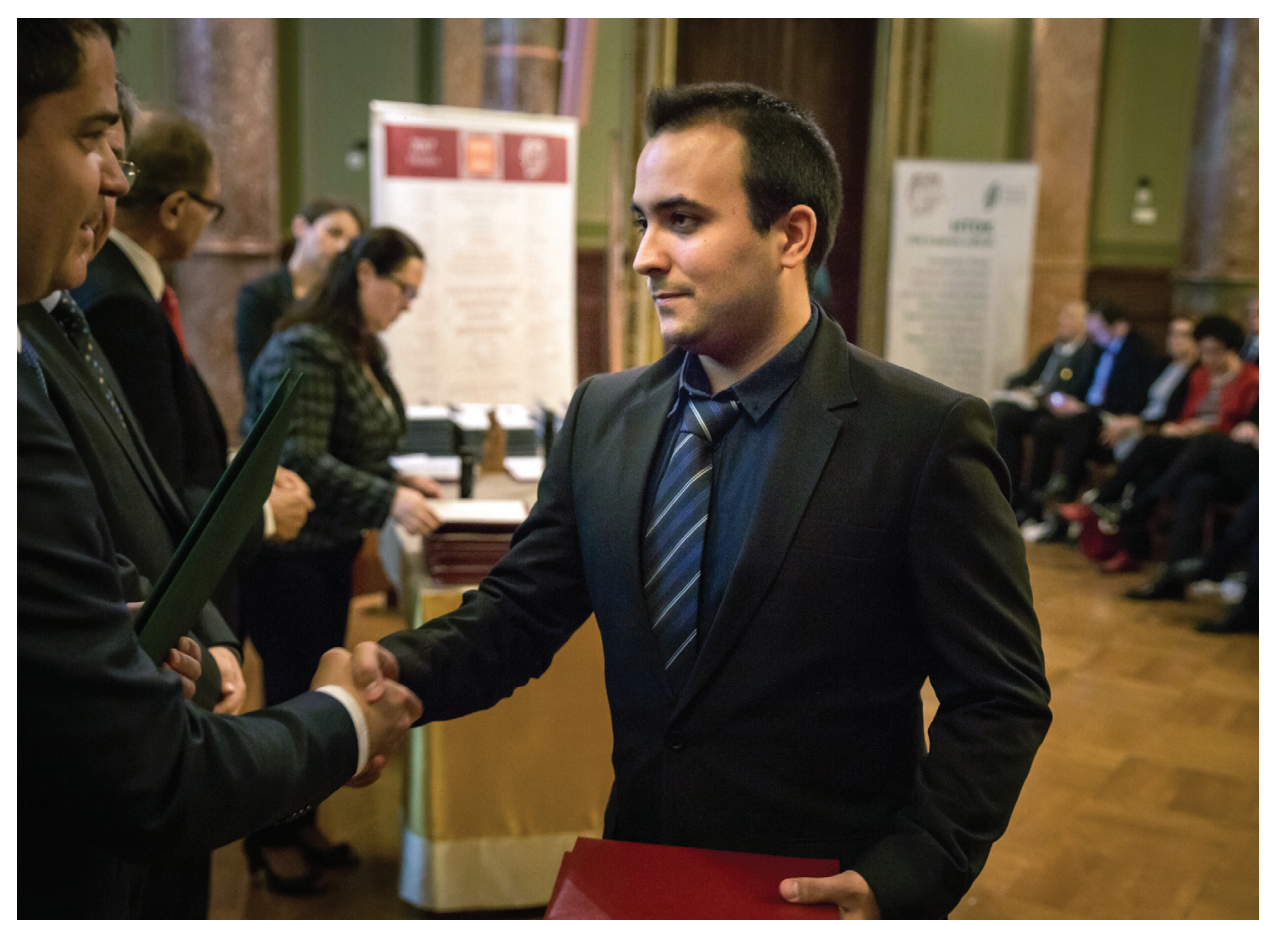

1. kép. Nagy Andor átveszi a Pro Scientia Aranyérem kitüntetést az OTDT ünnepi ülésén a Magyar Tudományos Akadémián 2017 novemberében (fotó: Nagy Gábor) 
Ahogyan a fenti hallgatói vélemény is mutatja, a tudományos diákköri tevékenység kiváló lehetőség a kötelező tanulmányokon felüli ismeretek elsajátítására, illetve olyan tudás és készségek megszerzésére, amelyek a későbbiekben segíthetnek a munkaerőpiacon történő elhelyezkedésben elsősorban az akadémiai szférában, de a versenyszférában és a közigazgatásban is.

A tudományos diákkör elsősorban - de nem kizárólag - a kutatás „előszobájának" tekinthető. Segítségével a felsőoktatásban tanulók megismerik a kutatás, a felfedezés izgalmát, ami a későbbiekben számos esetben kiemelt szempont lehet, amikor dönteniük kell arról, hogy milyen hivatást választanak maguknak. A kutatás világába történő betekintés, a tudományos igényű kíváncsiság és a „Heuréka-élmény" megélése kulcstényezők ahhoz, hogy a fiatalok saját maguk tapasztalják meg azt a szellemi kiteljesedést, melyet a kutatás, az alkotás jelent.

A felsőoktatási hallgatók tudományos pályára orientálásának egyik kiemelt eszköze a tudományos diákkör. Érdemben járul hozzá ahhoz, hogy a Fokozatváltás a felsőoktatásban felsőoktatási stratégia (URL1) egyik fontos célja - miszerint növekedjék a kutatói létszám - megvalósuljon. Ez a cél nem önmagáért való; ugyanis ismert tény, hogy a mesterséges intelligencia egyre szélesebb körü használatával fokozatosan csökken azoknak a munkaköröknek a száma, melyek ismétlődő, rutintevékenységeket tartalmaznak, hiszen ezek könnyen kiválthatóak mesterséges intelligenciával. Voltaképpen csak az ezzel járó költségek lassítják valamelyest ezt a folyamatot. A kutatás és a piacon is hasznosuló formája, az innováció éppen olyan terület, ahol a rutinok, ismétlések nem alkalmazhatók (legfeljebb a kutatás egy részében, a módszertanban). Ha Szent-Györgyi Albert gondolatában, miszerint „kutatni annyi, mint látni, amit mindenki látott és gondolni, amit senki sem gondolt”, a „kutatni” szót a kutatás alkalmazásához kapcsolódó 'innoválni' szóval helyettesítjük, világossá válik, hogy a kutatói szemléletmód nemcsak tisztán a kutatásokban hasznos, a mindennapi érvényesülésben is kiemelt szerepe van.

Nem véletlen, hogy a jövő munkaerőpiacán való érvényesüléshez szükséges kulcskompetenciák között is már az alapkészségek között azonosították a tudományos ismereteket a szakértők 2016-ban, a Világgazdasági Fórumon (URL2):

1. Alapkészségek (a mindennapi élethez):

- írástudás

- számolás

- tudományos ismeretek

- infokommunikációs ismeretek

- pénzügyi ismeretek

- kulturális és polgári ismeretek

2. Kompetenciák (összetett kihívásokhoz):

- kritikus gondolkodás, problémamegoldás

- kreativitás 
- kommunikáció

- együttmüködés

3. Karakter tulajdonságok:

- kíváncsiság

- kezdeményezés

- kitartás

- vezetői készség

- szociális és kulturális tudatosság

A tudományos diákköri tevékenységben való részvétel ezek jelentős részét fejleszti (1. táblázat).

1. táblázat. A jövő munkaerőpiaca által igényelt készségekről és arról, hogy a TDK hogyan járul hozzá ezek fejlesztéséhez

\begin{tabular}{|c|c|}
\hline Kulcskompetencia & Hogyan fejleszti a TDK? \\
\hline Írástudás & Pályamunka írása: tudományos jellegủ írásos mủ készítése. \\
\hline $\begin{array}{l}\text { Tudományos } \\
\text { ismeretek }\end{array}$ & $\begin{array}{l}\text { A TDK elsődleges célja, hogy a hallgatók kutatási és tudományos } \\
\text { ismeretei bővüljenek. }\end{array}$ \\
\hline $\begin{array}{l}\text { Infokommunikációs } \\
\text { ismeretek }\end{array}$ & $\begin{array}{l}\text { A kutatás, valamint a pályamunka írása és a prezentáció készítése } \\
\text { egyaránt hozzájárulnak az infokommunikációs ismeretek fejlesztéséhez. }\end{array}$ \\
\hline $\begin{array}{l}\text { Kulturális és polgári } \\
\text { ismeretek }\end{array}$ & $\begin{array}{l}\text { Erre a TDK-ban való részvétel inkább közvetve hat, mások kutatásainak } \\
\text { megismerésével, a tudományos kérdések közös megvitatásával } \\
\text { (kiemelten értelemszerüen leginkább a müvészetek területén). }\end{array}$ \\
\hline $\begin{array}{l}\text { Kritikus gondolkodás } \\
\text { és problémamegoldás }\end{array}$ & $\begin{array}{l}\text { A tudományos kutatásokban való részvétel egyértelmüen fejleszti ezen } \\
\text { kompetenciákat. }\end{array}$ \\
\hline Kreativitás & $\begin{array}{l}\text { Jóllehet a kreativitás készség, a tudományos kutatásban való részvétel } \\
\text { hozzájárulhat a fejlesztéséhez. }\end{array}$ \\
\hline Kommunikáció & $\begin{array}{l}\text { A pályamủ megírása az írásbeli, míg az előadás és az azt követő vita } \\
\text { a szóbeli kommunikációs kompetenciák fejlesztéséhez járulnak hozzá. }\end{array}$ \\
\hline Együttmüködés & $\begin{array}{l}\text { Ez tudományterületenként eltérő, leginkább ott járul hozzá a TDK } \\
\text { a fejlesztéséhez, ahol kutatócsoportokban folyik a munka. Ugyanakkor } \\
\text { a pályamunka nyilvános bemutatása és megvitatása is fejleszti } \\
\text { az együttmüködést, a közös gondolkodásra serkentést. }\end{array}$ \\
\hline Kíváncsiság & $\begin{array}{l}\text { A kutatás nélkülözhetetlen eleme a kérdésfelvetés. Az elörehaladás } \\
\text { során a megszülető válaszok pedig általában okot adnak további } \\
\text { kérdések feltevésére. }\end{array}$ \\
\hline Kezdeményezés & A kezdeményezésnek a kutatás előrehaladásában van fontos szerepe. \\
\hline Kitartás & $\begin{array}{l}\text { A kutatás nemcsak sikerekkel, hanem kudarcokkal is jár. Hosszú } \\
\text { és kitartó munka szükséges ahhoz, hogy tényleges eredményeket } \\
\text { érjenek el a TDK-zó fiatalok. }\end{array}$ \\
\hline
\end{tabular}


A tudományos diákköri tevékenység 1951-től (Anderle, 2011,29.) része a magyar felsőoktatásnak, azóta jelent lehetőséget a kötelező tanulmányokon felüli ismeretek elsajátítását célzó fiataloknak, valamint a hallgatókat segítő oktatóknak. A TDK az elmúlt több mint hatvan évben együtt fejlődött a magyar felsőoktatással, és ennek során épült ki az a hálózat, amely segíti a müködését (CzirákiSzendrö, 2016, 386-387.).

A hallgatók igénye a TDK iránt folyamatos, ami közvetve azt is mutatja, látják és tudják, hogy fontos fejleszteniük az előzőekben ismertetett kulcskompetenciáikat. Mindehhez nélkülözhetetlenek azok az oktatók, kutatók, akik elkötelezettek az iránt, hogy segítsék a fejlödésben a motivált fiatalokat, átadják számukra a tudásukat. Ehhez nem elegendő a témavezető szakmai ismerete, a mester-tanítvány viszony kialakulásához a tanári-munkatársi habitus további tényezői is szükségesek.

\section{A XXXIII. ORSZÁGOS TUDOMÁNYOS DIÁKKÖRI KONFERENCIA ELŐKÉSZÍTÉSE}

A TDK tehát sajátos értéke a felsőoktatásnak, amely hagyományait, céljait tekintve állandó, módszerei, eszköztára pedig folyamatosan fejlödik. Így válik hitelessé a mondás: A TDK örök! Mindennek az eredménye az, hogy 2017-ben már a XXXIII. Országos Tudományos Diákköri Konferenciára kerülhetett sor. A XXXIII. OTDK előkészítése már 2014-ben megkezdődött, az Országos Tudományos Diákköri Tanács ugyanis akkor választotta ki a rendező intézményeket, amelyek képviselői a 2015. évi XXXII. OTDK szekcióinak zárórendezvényén átvették a rendezés jogát jelentő stafétát, és megkezdték a felkészülést.

A szekciók felhívásait 2015 decemberében fogadta el az Országos Tudományos Diákköri Tanács (OTDT), ekkor váltak ismertté a pályamunkák tartalmi és formai követelményei. Szintén a szekciófelhívások tartalmazták az írásbeli és a szóbeli értékelés szempontrendszerét, amely alapján az OTDT tudományterületi szakmai bizottságai és a rendező intézmények közösen dolgozták ki az értékelő lapokat. A felhívások megjelenését követően 2016 februárjában a felhívásoknak megfelelően megkezdődött a dolgozatok feltöltése az OTDT online rendszerébe.

\section{ÍRÁSBELI BÍRÁLAT ÉS SZÓBELI ÉRTÉKELÉS}

A feltöltött pályamunkák közül végül 4455-öt neveztek be a XXXIII. OTDK-ra. A nevezéseket az OTDT Titkársága és a rendező intézmények ellenőrizték, ezt követte az írásbeli értékelés szakasza. Írásbeli bírálatot tizenöt szekcióban készí- 
tenek a dolgozatokhoz. ${ }^{1}$ Az írásbeli bírálat, valamint a szakmai zsürizés a legfontosabb eleme egy-egy OTDK-rendezésnek. Ennek első lépése a beérkezett pályamunkák tagozatokba sorolása. A tagozatok lényege, hogy egy-egy szekción belül szűkebb körben történhessen az értékelés. Az OTDT szabályai szerint ezért egy tagozatban legalább öt és legfeljebb tizenöt pályamunka bemutatása lehetséges. ${ }^{2}$ A tagozatokba sorolt pályamunkák írásbeli értékelésén mintegy háromezer bíráló dolgozott, ennek eredményeként több mint nyolcezer bírálat készült a tizenöt szekcióban. Az írásbeli bírálatokat az OTDT online rendszerében rögzítették, és a későbbiekben a hallgatók ott tudták azokat megtekinteni.

Az írásbeli bírálók kiválasztásának módszertana szekciónként eltérő: van, ahol a zsüritagok a bírálók is egyben, ezen belül is van olyan szekció, ahol ugyanaz a két zsüritag bírálja el az összes dolgozatot, és olyan is, ahol szétosztják a dolgozatok bírálatát a zsủritagok között, és így ugyanaz a három-öt ember bírálja el őket, de nem bírál mindenki mindent. A másik út az, hogy a dolgozatokhoz keresnek bírálót, azaz a bírálás és a zsűrizés folyamata elkülönül egymástól. Ami fontos, hogy minden dolgozathoz legalább két írásbeli bírálat készül, emellett vannak szekciók, amelyek meghatároztak egy pontkülönbséget a két bírálat között, és úgy döntöttek, ha annál nagyobb az eltérés, akkor harmadik bírálót kérnek fel. Emellett vannak olyan szekciók is, amelyek nem a harmadik bírálós megoldást választották, hanem a két bíráló konzultációját, amelynek eredményeként megváltozhatnak (a hallgatók által még nem ismert) bírálatok.

Abban is jelentősek az eltérések, hogy az egyes szekciók mikor teszik közzé a bírálatokat: az OTDK előtt vagy után. Az OTDK elötti publikálás esetén a hallgatók az előadásukban már reagálhatnak az írásbeli észrevételekre, míg az OTDK utáni közzététel esetében a bírálatok nem befolyásolják a hallgatók szóbeli prezentációját.

Az előadásokat a hallgatók a tagozatokban tartják meg, azok hossza 10-15 perc, amelyet vita követ. Ez tulajdonképpen a legizgalmasabb része az OTDK-nak: az eredmények szóbeli prezentációja, majd a zsüritől és a közönségtől érkező kérdések és az arra adott válaszok során az adott tudományterület elismert oktatói, kutatói visszajelzést adnak az elhangzottakról, amelynek eredményeként valódi párbeszéd alakul ki.

Az írásbeli bírálatok és a szóbeli előadás értékelése határozzák meg az OTDK szakmai minőségét. A megjelenő fiatalok azt várják, hogy eredményeiket megmutathassák, megmérettethessék, és azokról az idősebb generációk tagjaival érdemi

${ }^{1}$ Az Orvos- és Egészségtudományi Szekció hagyományai szerint csak előadást nyújtanak be a hallgatók, dolgozatot nem. Emellett a Müvészeti és a Mủvészettudományi Szekcióban csak az elméleti pályamunkákhoz készül írásbeli bírálat, a müvészeti alkotások esetében más az értékelés módszertana.

${ }^{2}$ Forrás: a XXXIII. OTDK Központi Felhívása: URL3 (letöltve: 2018. április 13.). 
egyeztetést folytathassanak, amelyet aztán a későbbiekben is fel tudnak használni. Épp ezért kiemelt jelentőségü a tagozatok összeállítása, a zsüritagok és az írásbeli bírálók kiválasztása és felkészítése. Nagyon fontos ugyanis, hogy ők is tudják és értsék kiemelt szerepüket a résztvevők életében, és a kommunikációjukkal (akár írásbeli, akár szóbeli) segítsék azokat, akik többletmunkát végeztek. A szakmai segítség mellett nagyon fontos a motiválás is, a kritika olyan megfogalmazása, amely nem elveszi a kedvet, hanem sokkal inkább további kérdések feltevésére motivál. Ezt tudják a szekciók rendezői és az OTDT szakmai bizottságainak tagjai is, épp ezért megfigyelhető, hogy az utóbbi időben a szakmai bizottságok folyamatosan fejlesztik a bírálói és a zsüritag adatbázisaikat és a kiválasztási módszertanukat.

\section{A XXXIII. OTDK SZEKCIÓINAK ÜLÉSEI}

A XXXIII. OTDK 2017. március 23 -án kezdődött Győrben, a Tanulás- és Tanításmódszertani és Tudástechnológiai, valamint a Testnevelés- és Sporttudományi Szekció közös nyitó rendezvényén, és 2017. április 27-én zárult a Had- és Rendészettudományi Szekció díjkiosztóján. A 2. kép a XXXIII. OTDK Biológia Szekciójának regisztrációját mutatja be.

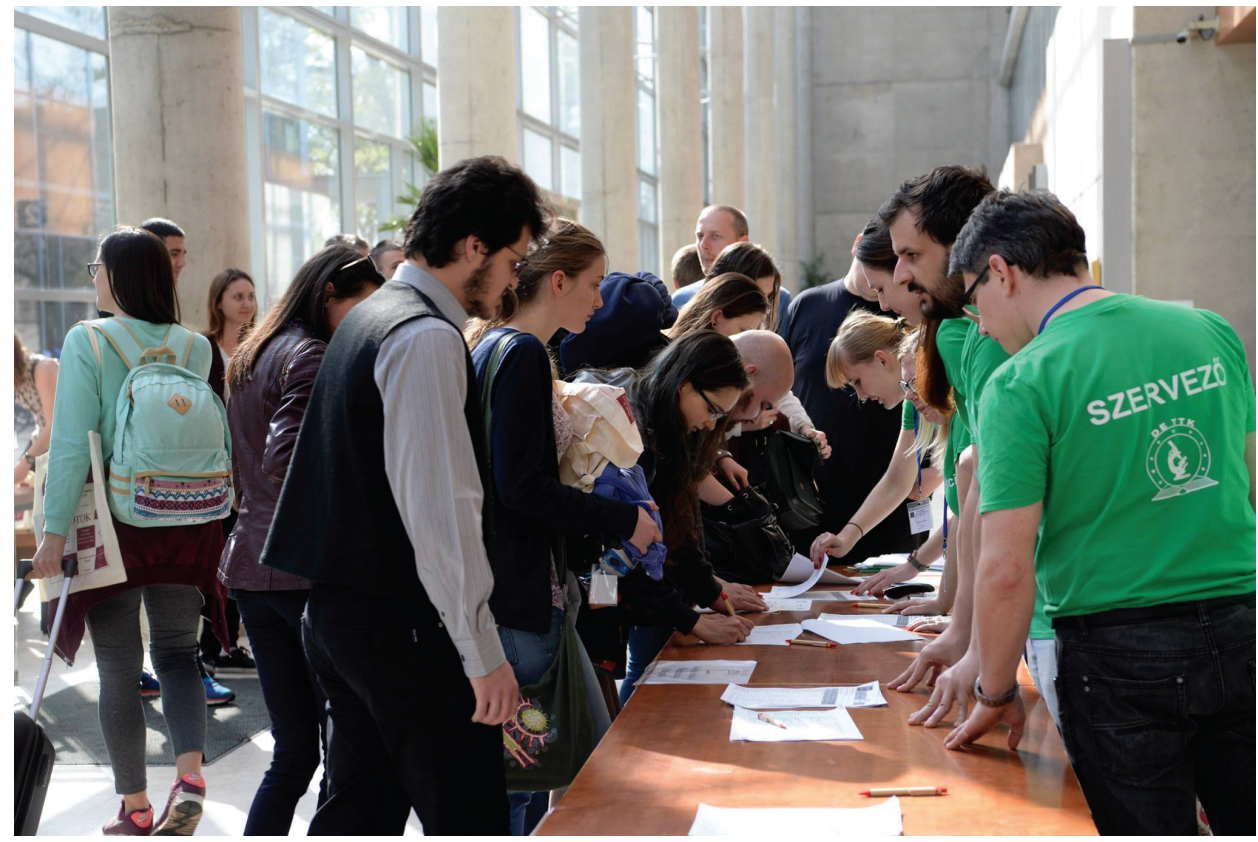

2. kép. Életkép a XXXIII. OTDK-ról (fotó: Bódi Sándor) 
Ezen időszak alatt 505 tagozatban összesen 4111 pályamunka bemutatása történt meg. A szekcióktól kapott visszajelzések alapján elmondható, hogy a magas (de az előző OTDK-hoz képest még így is kevesebb) dolgozatszám mellett a színvonal is megfelelő volt. A hallgatók szóbeli kommunikációja és vitakészsége sokat fejlődött az előző OTDK-(k)hoz képest, csakúgy, mint a prezentációk színvonala. Az írásbeli kommunikációra ugyanakkor jobban oda kell figyelni, és abban is jobban kell támogatniuk a témavezetőknek a hallgatókat. ${ }^{3}$

Az írásbeli és a szóbeli értékelés során kapott pontok alapján alakult ki a tagozatok eredménye. Az OTDK szabályai szerint legfeljebb a bemutatott pályamunkák egyharmada kaphat 1., 2. vagy 3. helyezést, és legfeljebb 50\%-uk különdíjat és/vagy helyezést. További szabály, hogy egy tagozatban legfeljebb egy darab első helyezés adható ki, ami nem megosztható (a tagozati létszámtól függően 2. és 3. helyezésekből többet is oda lehet ítélni). A XXXIII. OTDK 505 tagozatában 501 első, 552 második és 285 harmadik helyezést értek el a résztvevők.

\section{A XXXIII. OTDK FINANSZÍROZÁSA}

A XXXIII. OTDK rendezői, valamint a pályamunkákat delegáló intézmények a Nemzeti Tehetség Program pályázatain keresztül kaptak támogatást, amelyet az Emberi Erőforrások Minisztériumának oktatásért felelős államtitkára egészített ki 200 millió Ft-tal, az OTDK teljes költségvetése így 2017-ben meghaladta a 400 millió Ft-ot. Minderre szükség is volt, ugyanis a költségek jelentősen emelkedtek: a szállás és az étkezés, valamint az ezt terhelö adók jelentették ennek legnagyobb részét (összesen 50\%-ot), a többi költség típusa és megjelenése nagyrészt a rendező intézmények saját vállalásaitól és lehetőségeitől, valamint a szekciók hagyományaitól függött (például, hogy az elismerő oklevél mellett van-e egyéb díjazás stb.).

\section{PRO SCIENTIA ARANYÉREM ÉS MESTERTANÁR ARANYÉREM}

Az OTDK első helyezettjei (az aktuális OTDK, illetve az azt megelőző OTDK, amennyiben az aktuális OTDK-n is mutat be pályamunkát a hallgató) pályázhattak a Pro Scientia Aranyéremre. Összesen 313-an adták be pályázatukat, amelyeket két körben értékeltek (a Pro Scientia Aranyérem Szabályzatban foglaltaknak megfelelöen).

Első körben az OTDT tizenhat szakmai bizottsága véleményezte a pályázatokat, és terjesztette fel azt az öt-öt hallgatót, akiket a legjobbnak találtak. Az így felterjesztett nyolcvan pályázó közül a Pro Scientia Aranyérem Odaítélő

\footnotetext{
${ }^{3}$ A XXXIII. OTDK szekcióinak szakmai beszámolói URL4 (letöltve: 2018. április 13.).
} 
Bizottság (és három albizottsága) választotta ki azt a negyvenöt fiatalt, akik Pro Scientia Aranyérmet, és azt a kettőt, akik művészeti teljesítményükért Pro Arte Aranyérmet nyertek 2017-ben. A Pro Scientia Aranyérem pályázat a teljes hallgatói életút elismerésére szolgál. Az OTDK első helyezés csak feltétel, emellett más TDK-eredmények, valamint a publikációk, konferencián történő előadások, tanulmányutak is számítanak.

A Pro Scientia Aranyérem pályázat lebonyolításával párhuzamosan történt a Mestertanár Aranyérem szakmai bizottsági keretének odaítélése is. A Mestertanár Aranyéremre a felsőoktatási intézmények és karaik tehetnek jelöléséket, szekciónként két före. Jelölt az lehet, aki legalább tízéves TDK-témavezetői és/ vagy TDK-szervezői múlttal rendelkezik. A Pro Scientia Aranyérem pályázathoz hasonlóan első körben az OTDT szakmai bizottságai értékelték a felterjesztéseket, majd sorrendben megnevezték azt az öt oktatót/kutatót, akiket javasoltak a Mestertanár Aranyéremre. A listák alapján az egyes szekciókban annyi Mestertanár Aranyérem került kiosztásra, ahány hallgató az adott szekcióban Pro Scientia Aranyérmet nyert. Így ebben a szakaszban negyvenhét Mestertanár Aranyérem került odaítélésre. További nyolc Mestertanár Aranyéremről az OTDT Elnöksége döntött, így összesen ötvenöten kapták meg 2017-ben a kitüntetést.

A Pro Scientia Aranyérem és a Mestertanár Aranyérem kitüntetések, valamint az OTDT további kitüntetéseinek átadására 2017 novemberében került sor a hagyományoknak megfelelően a Magyar Tudományos Akadémia Dísztermében. A Pro Scientia Aranyérmeket az OTDT elnöke Lovász Lászlóval, a Magyar Tudományos Akadémia elnökével, a Mestertanár Aranyérmeket Balog Zoltánnal, az emberi erőforrások miniszterével közösen adta át.

A Pro Scientia Aranyérmesek Csányi Attilától, a Bonafarm Zrt. vezérigazgatójától kaptak támogatást (személyenként 200000 Ft-ot). Első alkalommal volt lehetőség arra, hogy a hallgatói támogatással egyező mértékü díjat kapjanak a Mestertanár Aranyéremmel kitüntetett oktatók/kutatók is, a Magyar Nemzeti Bank elnökének, Matolcsy Györgynek a felajánlásában.

Az OTDT novemberi ünnepi ülésén hivatalosan is lezárult a XXXIII. OTDK. A tanács az ünnepi ülés után rendes ülést is tartott, amelyen megköszönték a rendezők munkáját, és átadták a megbízóleveleket a XXXIV. Országos Tudományos Diákköri Konferencia rendezőinek.

\section{A TDK FOLYTONOSSÁGA}

A XXXIII. OTDK szekcióinak rendezvényeivel párhuzamosan folytak azok az intézményi és kari TDK-konferenciák, amelyeken a 2019. évi XXXIV. OTDK-ra szerezhettek jogosultságot a hallgatók. A tapasztalatok azt mutatják, hogy a TDK felértékelődik, amihez nagyban hozzájárul az is, hogy a hallgatók látják, a TDK 
jelentősen hozzájárul azon kompetenciáik fejlesztéséhez, amelyek egyre fontosabbá válnak a munkaerőpiacon. Mindez nagy feladat elé állítja a témavezetőket, a felsőoktatási intézmények TDK-szervezeteit, az Országos Tudományos Diákköri Tanácsot és szakmai bizottságait, valamint a rendező intézményeket egyaránt, hiszen a korábbi kimagasló mennyiségi fejlődést követően (az elmúlt tíz évben az OTDK-n bemutatott pályamunkák száma közel 50\%-kal nőtt, de a folyamatok azt mutatják, további mennyiségi fejlődés már nem várható) a hagyományokat megőrző minőségi fejlesztések kerülnek a fókuszba: egyre fontosabbá válnak a minőségi bírálatok és a tagozati üléseken a valódi párbeszéd kialakítása. Épp ezért az OTDT kiemelt figyelmet fordít ezen területekre, és ösztönzi a szakmai bizottságokat és a rendezőket is, hogy az előkészítés és a lebonyolítás során folyamatosan ez legyen a fókuszban. Mindezt segíti, hogy a 2019. évi XXXIV. OTDK teljes finanszírozását biztosítja az Emberi Erőforrások Minisztériumának Oktatásért Felelös Államtitkársága.

A TDK időtálló sikere arra épül, hogy a hagyományok tiszteletben tartásával lassan fejlődik, és egy meglévő igényen, a hallgatók többlettudás megszerzésére irányuló törekvésén alapul. Mindehhez persze kellenek azok az elkötelezett oktatók és kutatók, akik fáradhatatlanul küzdenek azért, hogy a fiatal tehetségeket segítsék, akik ennek köszönhetően szélesebb körü tudásra és ismeretekre tesznek szert, így a felsőoktatási tanulmányaik befejezését követően jobb eséllyel indulnak el a kutatói pályán, illetve más szektorokban munkavállalóként. A mondás, miszerint A TDK örök!, nemcsak szlogen tehát, hanem tény.

\section{IRODALOM}

Anderle Á. (szerk.) (2011): A magyar tudományos diákköri konferenciák története (1951-2011). Budapest: Oktatáskutató és Fejlesztő Intézet

Cziráki Sz. - Szendrő P. (2016): Tudományos diákkörök. Educatio, 4, 386-387. http://www. edu-online.eu/hu/educatio_reszletes.php?id=115

Nagy Andor, 2017. évi Pro Scientia Aranyérmes hallgató. In: Gerencsérné Újvári Edit (szerk.): Miért jó a TDK? Hallgatói vélemények a tudományos diákköri munkáról. Szegedi Egyetemi Kiadó Juhász Gyula Felsőoktatási Kiadó, http://www.jgypk.hu/otdk2017/wp-content/uploads/2016/10/Mi\%C3\%A9rt-j\%C3\%B3-a-TDK.pdf

URL1: Fokozatváltás a felsőoktatásban stratégia. A teljesitményelvü felsőoktatás fejlesztésének irányvonalai. http://www.kormany.hu/download/c/9c/e0000/Fokozatvaltas_Felsooktatasban_ HONLAPRA.PDF (letöltve: 2018. május 7.)

URL2: What Are the 21 st-Century Skills Every Student Needs? https://bit.ly/29Imwr5 (letöltve: 2018. március 8.)

URL3: A XXXIII. OTDK Központi Felhívása, http://otdt.hu/hu/xxxiii-otdk-felhivasok

URL4: A XXXIII. OTDK szekcióinak szakmai beszámolói, http://otdt.hu/hu/xxxiii-otdk-szakmai-beszamolok 